\title{
Does the State Really Exist? A Perspective from the Transcendent Philosophy of Mullā Șadrā
}

\author{
Cecep Zakarias El Bilad*
}

Abstract: $\quad$ This research comes from a simple question whether the state exists in the real world or is only a fiction in the mind. In International Relations (IR), the state is often conceptualized as if she is an individual that has certain qualities of personality. The concept, however, is actually considered as a metaphor only or an as if person. What really exist in the extra-mental world are those individuals "in" it. If that is the case, then why the effects of its existence are so real and can be felt by everyone? And, how can IR be scientific while its object of study is a fiction? The neglect of the state's existence is rooted in the empirical epistemology held by most IR thinkers and students especially since the wave of scientification of the discipline began in the 60's. They hold the empirical view that knowledge stems primaliry from the sensory experience, and anything beyond it has no certainty. The similar neglect is, in fact, shared also among non-empirical IR thinkers coming about in the later decades such as postmodernists and constructivists, because of their idealist ontology that there is no any objective reality but constructed discoursively. This research wants to analyze the ontological status of the state from the perspective of Mulla Sadrä's transcendent philosophy. His philosophical system that primarily concerns on the existence qua existence and the existential structure of realities, serves as the foundation of any discussion about the existence of entities, without exeption that of the state.

Keywords: $\quad$ Existence, Reality, State, Soul, Individual, Society, Mind

\footnotetext{
The Islamic College for Advanced Studies (ICAS) - Paramadina University, Jakarta, Indonesia, cecepelbilad@gmail.com
} 


\section{Introduction}

From its birth in 1919, International Relations (IR) has experienced significant growth. The ongoing academic debate has spawned many paradigms, the cornerstones of a normal science, such as realism, liberalism, constructivism, critical theory, postmodernism, feminimisme, and so forth. As Thomas Kuhn says, a branch of sciences has reached a normal level if it already has an agreed paradigm. ${ }^{1}$ IR has far exceeded it, and interparadigm debates continue to this day.

Since the 1990s' development, the debates have increasingly gone philosophical and begin to encroach on ontology, after decades of struggle in the area of practical issues, theory, methodology and epistemology. Since then new paradigms have been presented such as scientific realism and critical realism, as alternatives to the existing philosophical bases like empiricismpositivism, constructivism and postpositivism. One of the ontological problems raised, for example, is whether the state is real in the real world like humans, animals and other tangible objects, or simply an abstraction in the mind?

For the mainstream like neorealists and neoliberalists who hold the empiricist belief that everything which cannot be sensually observed cannot be confirmed or acknowledged as a real, while the state is not seen by the eyes it is doubtful to be an existent in the real world. If it is so, however, then why is it believed to be the major actor in the international life and claimed to serve as IR main subject of study? The state, with its unclear ontological status, even is often dressed some individual traits such as advanced, developing, underdeveloped, rich, poor, dignified, or such individual activities like cooperating, going war, making peace, organizing, promising, competing, and so forth. If it is acknowledged to be real, it does make sense that it is pinned to such human attributes. But if its reality is denied and assumed to be a mere abstraction in the mind, it means the embedment is just an imaginative game.

Here we will only outline some views on the problem of the state's existence, both from the empiricist and nonempiricist. We will also present some conceptions of the state from the nonWestern thinkers which deserve to be juxtaposed here. Then we will express our own arguments based on the principles of hikmah muta'āliyyah (transcendent philosophy) of Mullā Șadrā. As will be explained, this problem is also closely related to the philosophical theme, consciousness or mind-body problem, which, as Alexander Wendt said, would never satisfactorily be explained with physicalism in general or empiricism in particular. Consciousness, along with ontology and epistemology, is described in detail in Mulla Sadra's philosophy. Therefore, it is very likely to be offered as the alternative philosophical foundation to deal with the problem of the state's existence.

\section{A. The State and Its Existential Problem}

Conceptually, the state is a society or social community that has, at least, the five essential qualities: (1) territorial (a fixed position in space); (2) public politics (clear division between the private and public sphere); (3) political institutions; (4) multiplicities of governmental function and activities; (5) legitimizing authority structures. ${ }^{2}$ The qualities give the state a unique attribute that sets it apart from the types and forms of societies ever existing in history, namely sovereignty. Sovereignty is the legality of a political organization (the state) for being independent. ${ }^{3}$ Like humans who associate with each others, so do states. Sovereignty is a state's social capital to enter the international arena. Exactly like humans, in order to optimize the results of the association, states form norms, regimes and international organizations.

In practice, however, they are individuals who do and practice the association. So, which one actually exists in the real world, the state or the individual? Among few IR scientists who "care" about it, Erik Ringmar specifically discussed it in the article "On the ontological status of the State" in the European Journal of International Relations in 1996. He pointed out that there were two answers. The first, the state is not a true figure, but just a metaphorical concept that refers to particular empirical attributes such as people, government, military troops, territorial and 
so forth. This answer belongs to David Hume and represents most positivist-empiricist IR scientists like neorealists and neoliberalists.

The second answer comes from Thomas Hobbes that it exists transcendentally. It is composed of individual, each of which has the lust for mastering each other. The state is the Leviathan, an artificial person who is in charge of managing the distribution of power among the individuals and creating an order. ${ }^{4}$ Hobbes (1588-1679) is a British philosopher whose conception on humans and Leviathan is so popular among IR thinkers and students and has inspired the neorealist camp to formulate the theory on international anarchy. ${ }^{5}$ His view on the state's ontological status, however, seems less attractive to the most. They choose to follow Hume. A prominent realist, Robert Gilpin, for example, vulgarly says, "of course we realists know that the state does not really exist." What really exist from all discourses about the state, both at the national and international level, are the individuals. Social or political entities called "states" are only considered as if they exist and perform activities. ${ }^{6}$

A different view is given by Herbert Spencer (1820-1903). He argues that the state is a living organism, and it grows or evolves. ${ }^{7}$ It is a social organism, which is an entity that is composed of living nerve-centers called humans. It works like a machine. If the machine is composed of inorganic spare parts and works as it is driven by the inorganic forces as well as steam and water, then the state as a social oganism is structured, works and grows by the power of the living nerves. ${ }^{8}$ Although Spencer was not an IR thinker, this view, at least, represents a kind of empiricist philosophers on this topic.

Like other empirical theories, the social organism theory still leaves some ontological problems. Spencer sees the state as a mere physical entity, that the organism (the state) is formed and driven by a set of living nerve-centers. Like a human, the animal is also a body composed of living nerves. So, does a bunch of animals in some area reserve the right to be called the state? Then, when a group of people gather in a place, does they automatically create the state? Spencer's basic problem here is just that he is a materialist and considers a man a physical entity only composed of living nerves.

The empiricist-positivist's deadlock on this issue has been recognized by the leading IR constructivist Alexander Wendt. He then tried to look for an alternative ontology used as the basis for formulating a solution, and he found it on scientific realism (SR), a variant of realism philosophy. Realism's basic principle says that reality exists and its existence is independent of the mind (human). ${ }^{9}$ Up here, empiricists agree with realists because they also recognize the independence of reality. But realits continue that there are two kinds of realities, observable and unobservable. Unobservables are divided into two, detectable and undetectable. "Detected" means things that are invisible but their presence can be detected with the help of technologies such as microscopy, for example atoms and fragments. "Undetectable" means, the things that theoretically can be proved but can not be empirically detected, such as position and speed in the Newton's conception. With this perspective, Wendt argues that the state is an unobservable fact. It does exist, not just a fiction. When it is analyzed, the state refers to the physical elements which are detected and interrelated, such as the president, ministers, parliament, law, military, and so forth, but its existence is not reduced into such physical facts. The state does not have a physical body, but the effects of its presence can be felt by everyone. ${ }^{10}$ For example, if someone commits a crime, even though he may think the state is just a fiction, he will remain experiencing the physical effects of its existence: he will be arrested and imprisoned. But no one would assume that the police who arrest him are the state. The police is one of the state's elements. They do not do it on behalf of their own selves, but of the state they serve.

Having concluded that the state is real, Wendt then develops it and formulates the theory of the state as a superorganism. Superorganism is a human colony, just like the colony of bees or termites. It is a collection of individuals who have identical attitudes and organized behaviors, although they are not physically united into one body. ${ }^{11}$ So, what drives these individuals to organize themselves? The state's mind is not created by the body, but by the mind of its citizens. Wendt acknowledges that human is a living entity that is not fully physical. She also has a 
consciousness. Consciousness enables her to recognize herself and her environment. In the case of states or societies in general, physical unity is secondary. What is the core is the unity of consciousness among individuals called collective consciousness. ${ }^{12}$

Then, what about the ontological status of consciousness? Wendt does not investigate further, however he also doesn't accept physicalism's explanation which reduces the state to a mere empirical phenomenon. ${ }^{13}$ He then assumes that the problem of the ontological status of the state is likely to be explained better if we take panpsychism as the ontological basis, a branch of philosophy that sees consciousness exists outside the physical realities. ${ }^{14}$

Wendt's conclusion shows that the ontological problem has opened up the opportunity for more investigations, even up to going beyond the physical realm further into the metaphysical (non-spatiotemporal world). Without such an assessment we will never obtain a more comprehensive picture of consciousness. In philosophy, it is one of the major themes and has spawned its own branch, ie the philosophy of mind whose central theme is the mind-body problem. ${ }^{15}$ Almost all the philosophers of various schools have engaged in the talk about it with each own perspective. So far in the contamporary philosophy, indeed, the metaphysical discussion on the mind-body problem has been left behind. This, according to Robert Audi, is the effect of the success of modern sciences in explaining natural phenomena, including the human body, while the modern theories have been born from the womb of the materialism philosophy. Therefore, it raises an academic tendency to only recognize the philosophy of materialism and deny the presence of other schools of philosophy. ${ }^{16}$

Wendt's finding that the problem might only be solved by panpsychism constitutes a signal that this problem becomes an open topic to discuss from any philosophy that recognizes the duality of body and soul. This is the gateway for us here to engage with it from the perspective of transcendent philosophy (hikmah muta'äliyyah). The school of philosophy belonging to Mulla Sadra (1571-1640), the great Muslim philosopher of Persia, has comprehensive views of the mind-body problem. The abstract realities like concepts, ideas, and imagination obtain their clear ontological status in this philosophy.

\section{B. Alternatives from Non-Materialists: A Bridge}

The problem of the state's ontological status basically stems from the philosophical inconsistency of IR scientists themselves. The empiricists, on one side, reject the state's existence solely because it cannot be seen, but on the other they ironically argue about it and produce theories to explain states' behaviors. For the postpositivist camp such as postmodernists, the state's objective reality is also denied, because they believe that even physical objects such as animals and plants are not real. For them, all what are called realities both observable and unobservable, are discoursively constructed. ${ }^{17}$ Discourses or theories determine how the subject (individual) perceives the world. Like that of empiricists, such postmodernist ontological view also leaves some problems, but we will not discuss it here.

It is only to be informed here that the state's ontological status is a very fundamental issue. Discussion on it will be a critique and reconstruction of the philosophical bases of the existing paradigms in IR discipline. Every theory stands on a certain system of philosophy. Philosophy provides a paradigmatic framework for understanding the world as it is, so that we can determine how exactly we should study it. The mistake in this foundational realm will undermine all the truth claims about the objects studied.

In other part of the world, the ontological status of a social group or community has once been studied by Ibn Khaldun (1332-1406), a Tunisian Muslim thinker. Although the concept of states is not used in his discussion, his social theory about the formation of a political community as tribes (qabilah), city (madina), and nation (ummah) can be applied to the state, because it is also a kind of social communities. ${ }^{18}$ In this context, we would like to give an example of how a discussion of social theories can not be separated from the philosophical discussion. A theory is born from some philosophical paradigm of the world. Ibn Khaldun's sosio-political theory is here 
also as an example of the theory based on the non-materialist philosophy. The brief description of Ibn Khaldun's is necessary here, in order to bridge the gap between the position of Mulla Sadra's philosophy that concerns only on the metaphysics and International Relations as a branch of social sciences.

In his Muqaddimah, the first volume of his history book, Ibn Khaldun partly speaks about the birth of a civilization or a political society. At each level, a political society can exist because of 'asabiyyah, namely a primodial feeling among individuals which encourages them to group. Franz Rosethal translates it as "group feeling". ${ }^{19}$ 'Asabiyyah mainly bears from blood ties such as family, kinship and descent. Such biological bond raises a certain feeling among the individuals to help, respect and protect each other. ${ }^{20}$

Ibn Khaldun believes that human being is composed of the body and soul. The soul serves as the essence of humanity, and the body is only the locus for the soul's actualization in this natural world. ${ }^{21}$ All the body's activities and functions, including feeling and thinking, are driven and controlled by the soul.2 In every human soul, there is the innate potency for good and evil, which develops according to the education they receive from their parents and environment. In most humans, however, the potential for evil goes faster and dominates. For this reason, when living together they point out a leader and build a leadership system both of which serve to control and regulate the behavior of those individuals in order not to fight each other, as well as to protect them from the aggression of other groups. ${ }^{23}$

If it is referred, 'asabiyyah has a clear ontological status as a mental quality that appears on the individual members of a community. The theory is based on his eschatological views strongly affected by earlier Muslim philosophers, especially the peripatetic Ibn Sīnā. He argues that the soul is a substance that exists between the natural and angelic world (ifq al-maläikah). In relation to the body, the soul lives the body and moves all its parts. In relation to the upper world, the soul gains various types of knowledge both scientific and supernatural (ghaibiyyah). ${ }^{24}$

Another Muslim thinker who has the theory of the formation of society is Murtadhā Mutahhari (1919-1979), a contemporary Iranian thinker. In his book Society and History, Mutahhari defines society as a group of people who live together and are linked by a set of systems, customs, rites and laws. ${ }^{25}$ The existence of society is natural, because the nature of human is a social entity. The various physical and mental activities of a person are always related and involve other persons in certain patters of relationship. When numbers of individuals involved increas, a sense of unity and the same vision comes about among them. The process is carried out consciously by everyone involved in it. ${ }^{26}$

Mutahhari states that society is a real existence.$^{27}$ Empirically, it is composed of material elements such as a group of people, buildings, land, and so on. It is, however, not reduced to the existence of these elements. It is a cultural compound, not physical, which is made of the merging of the soul, mind, will and desire of the individuas. ${ }^{28} \mathrm{~A}$ series of intensive interaction processes between the individuals creates a new independent substance called social spirit. This synthesis, he adds, is unique and has no equality in the universe. It is a synthetic personality emerged from the reciprocal relationship between individuals involved, while physically they remind residing in their bodies. ${ }^{29}$

Mutahhari discusses the topic sociologically with little philosophical arguments. He is, however, personally a teacher of philosophy at the University of Tehran, and one of the great figures in the Sadrian schoold. He wrote a dense book on philsophy Durūs Falsafiyyah fi Sharh al-Mandhümah, containing an explanation of the book Mandhūmah by Mullā Hādī as-Sabziwārī (1797-1873) which is a summary of Mulla Sadra's system of philosophy. Therefore, his thought on the concept and existence of society is very likely inspired or based on Sadra's philosophy. 


\section{The Principles of Mullā Șadrā's Philosophy}

Muḥammad ibn Ibrāhīm ibn Yahyāa al-Qawwami al-Shirāzi or Mulla Sadra formulated his system of philosophy in the phenomenal book written in Arabic al-Hikmah al-Muta'äliyyah fi al-Asfar al'Aqliyyah al-Arba'ah. In the history of Islamic philosophy, hikmah muta'āliyyah Mulla Sadra is the latest school whose originality is built on the correction and development of the earlier schools of philosophy both Greek and Islamic philosophical tradition. It is a new genre that combines rationality of philosophy, "irrationality" of mysticism and revelation Here, we only outline some key principles of the philosophy, sufficient to formulate the status of the existence of the state.

\section{a. The Concept of Wujūd}

Etymologically, the word wujūd is translated as existence or being. According to Seyyed Mohammed Khamenei, conceptually wujūd is the opposite of the concept of "nihil" (al-'adam) or non-existence. ${ }^{30}$ First of all, it needs to be distinguished between wujūd as a concept and that in reality. As a concept, wujūd is a universal one. ${ }^{31}$ At the conceptual level, it is just an idea or abstraction in the mind, as any other universal concepts like man, animal, justice, goodness, and so on. It is not that in reality which is what we mean as the basis of all realities. It is the real wujūd which is to be the subject of discussion in Șadrā's philosophy.

Wujūd is the source of all existents. It cannot be defined, because it is "something" absolutely clear, which appears independently (dhahir bi nafsih) and simultaneously makes real something else other than herself (madhhar li ghairih), just as the light that becomes real by itself and makes a real objects other than herself. Everything can come out of the nothingness and turn to exist is due to the gift of existence from wujūd. While definition is an attempt to clarify anything that is unclear with something else that is clearer, no one can clarify "the existence" of wujūd because there is nothing clearer than wujūd. ${ }^{32}$

It is also undefined because a definition can only be given to something that has the genus and differential, while both can only be pinned to something that is limited and bound to something else. The thing is different from the other things because it has limits on itself. Everything can be "something" or existent only because it is given existence by wujūd. Wujūd is that which underlies the existence of things as well as their limits. Therefore the "existence" of wujūd must be superior and more perfect than these things. ${ }^{33}$ The laws and conditions applicable to such things like the genus-species categorization, surely do not apply to wujūd. Wujūd is perfect and its perfection is absolute.

\section{b. Aṣālat al-Wujū (Principality of Wujūd)}

Wujūd is that which underlies everything that exists. Things are diverse in quality, quantity, place, time, position, and so forth. The diverse things are what so-called realities. The diversity, therefore, is the nature of realities which is born of oneness and takes place only in the singleness, ie wujūd. ${ }^{34}$ What makes the differences between those things so that the human mind can distinguish onething from the other is called mâhiyyah 'quiddity' or 'essence'. Through quiddity, philosophers make the categorization of the genus (jins) and species (naw') based on the differential $(f a s l)$ to be applied to realities.

Thus, in every reality there are two sides at the same time when we perceive it, wujūd and quiddity. When we ask "does a tree exist?" we question the wujūd of the tree. When we ask "what tree is that tree or how does it look like?" we question the quiddity of the tree. However, this does not mean that the tree is in itself composed of two different things, wujūd and quiddity. The dualism is just an image in mind when we are seeing the tree.

On the question of which one is actually real in the real world, there are various answers among Muslim philosophers. Mulla Sadra himself provides that the real one is wujüd, while quiddity is a mental image. ${ }^{35}$ Quiddity is simply a mental abstraction of diverse realities/existents 
that we see all around. In the extra-mental world, what exists is only wujūd. In a simple language Fazlur Rahman says, "nothing is real except existence". ${ }^{36}$ Ontologically, quiddity could not be said existent (maujüdah) or nihil (ma'dümah). It is something that is captured by the mind after being illuminated with the light of wujūd by the Absolute Wujūd. Before being illuminated with wujūd, it remains in its original condition hidden as a non-existent. Neither it is itself nor other than itself. Neither it is wujūd nor nonexistent. ${ }^{37}$ It exists only in the mind when the mind sees the

| 82 diverse modes of wujūd in the real world.

\section{c. Tashkīk al-Wujūd (Gradation of Wujūd)}

The diversity of realities comes from the oneneness of the Absolute Wujūd. Then comes the question, "do the essential differences between realities mean the differences of their wujūd? How does the pattern of the relationship between the oneness of the Absolute Wujūd and the diverse realities/existents? The peripatetic philosopher Ibn Sina argues that the differences are not just on the quiddities of the realities, but also on their wujūd..$^{38}$ The illuminationist Suhrawardi answers, the differences do not occur in quiddities, let alone wujūd, but in the intensity or quality of the quiddities of these objects. ${ }^{39}$ Suhrawardi's view is based on the basic principle that what is real is quiddity and wujūd is only a mental abstraction.

Both views become the basis for Mulla Sadra to formulate his own. For him, all the differences are actually kinds of images that appear in the human mind called quiddities. It means, which differ are the quiddities of the realities while they are one in their wujüd. The real "thing" in the world is oneness (wahldah) and simplicity (bisātah) of wujūd. Diversity and difference are the effects captured by the senses and the mind off the modes of the graded wujūd (anha almukhtalifät at-tashkīkiyyah). ${ }^{40}$ Mulla Sadra agrees with Suhrawardi's illumination principle, that the diversity of realites occurs because of differences in the light intensity (tashaddud) emanating from the Ultimate Light, just as the sun emits light in various intensities and colors. Adopting this principle, Mulla Sadra finds that the multiplicity occurs as the result of the degrees of intensity of the graded wujūd. ${ }^{41}$

In its essence, the Absolute Wujūd is single, indivisible and unlimited (not limited by anything). However, in His absolute oneness, like the sun, the Absolute emanates His light in degrees of intensity. It means, the light $\mathrm{He}$ emanates has degrees of perfection and strength according to how far or closed the particles of light be to the source of radiance. ${ }^{42}$ Such particles in their various intensites of perfection are what the human mind captures as essential diversities and calls "things" or "realities". This principle is known as tashkikk al-wujüd (gradation of wujūd). However, the plurality that occurs in the gradation levels does not mean reducing or damage of the oneness of the Absolute Wujūd. The diversity can exist only in the singularity, as the blend of various colors in a painting only exists on the canvas with a single color, ie white. Can a beautiful painting be made on a colored canvas?

\section{d. Al-Wujūd adh-Dhihnī and al-Wujūd al-Khārij̄ī}

The topic of al-wujūd adh-dhihnī (mental existence) and al-wujūd al-khārijī (external existence), as in S.H. Khamenei says, is a bridge between ontology and epistemology in Sadra's philosophy. ${ }^{43}$ When we see a stone, for example, at the moment we transfer sort of data on the physical attributes of the stone into the mind. These data are then processed by the mind and manifest some sort of image or sketch of the stone. ${ }^{44}$ This cognitive shadow is stored in the mind's memory and serves as a guide to define what a rock is, or to be able to identify other objects that have similar characteristics to be categorized as "rock". This is called al-wujüd adhdhihnī (mental existence). Ideas and concepts are existentially included in this category of mental existence. Meanwhile al-wujüd al-khāriji is the real stone in the extra-mental world. In other words, the mental existent exists in the mind while the external is the external dimension of the former. 
Then, there is also a mental existent which only exists in the mental and does not have its actuality in the real world. For example, we could imagine a horse-headed human figure, decapod, golden-haired, caudate, and so on, without us considering the presence of this figure in the real world, and we created this figure as we wished, not based on a visual in the real world. The figure manifests in our mind only.

\section{e. Ma'qūlāt}

The division of wujūd into mental and external above serves as the ontological basis for the concept $\left(m a^{\prime} q \bar{u} l\right)$ which is a reality that is created by the mind and exists in it as an integral part of the human psyche. A concept ( $m a^{\prime} q \bar{u} l$, plural $\left.m a^{\prime} q \bar{u} l \bar{a} t\right)$ is a universal understanding or meaning of something. ${ }^{45}$ Concepts are divided into two, primary (ma'qūlāt awwaliyyah) and secondary (ma'qūlāt tsāniyyah). The primary concept is the understanding or meaning obtained directly from a particular reality in the real world through sensory perception. ${ }^{46}$ It means, immediately after the senses perceive or have contact with an object, the mind automatically abstracts an understanding of the object without an analysis or deep thought. For example, when we see a book, will appear in the mind an image (sürah) of the book which is called "sensual form" (sürah mahsüsah). Then, the image is saved by the sensory power (quwwah al-häfidhah) in the new quality of wujūd named "imaginary form" (surah khayāliyyah). With this process, the form of the book remains existing in the mind though the eyes no longer see the real physical book. The next process takes place by/in the dimension of the intellect (al-quwwah al-'aqliyyah). The imaginary form develops into the form of the intellect (surah 'aqliyyah) which is the whatness of the physical object. This is called quiddity (mähiyyah). Here, the concept of "book" has become a universal concept that can be attributed to other objects classified as a book.

The second type is secondary concept, i.e those acquired or abstracted through rational analysis and comparison between objects and/or between concepts. ${ }^{47}$ Secondary concepts are divided into two kinds, logical secondary concepts (ma'qūlāt tsāniyyah manțiqiyyah) and philosophical secondary concepts (ma'qūlāt tsāniyyah falsafiyyah). Secondary logical concepts are those acquired through an analysis, but in the usage they do not correspond or refer directly to any real object in the real world. Their existence is of mental dimension, and their meaning and realization are also in the mental corre lation, ${ }^{48}$ such as the concept of particular, subject, predicate, proposition, genus and species. Such concepts do not refer to any object in the real world and are used only in the discussion of logics.

Secondary philosophical concepts are the concepts that refer to the facts in the real world. They are not acquired directly but through a series of mental understanding upon the sensual objects, so that on the one hand they are mental existents, created and existing in the mental, but on the other hand they are correlated or grounded in objective phenomena in the extra-mental world. ${ }^{49}$ The concepts like causation, oneness (wahdah), diversity (katsrah), pontency (quwwah), actual $\left(f^{\prime} l\right)$, possible (mumkin), necessary (wäjib), something (shayiyyah), and so forth, are of this kind. For example, we say, "water is the cause of being wet". "Water" and "wet" are primary concepts because both physically exist in the real world and can be directly abstracted by the mind. Whereas "cause" is a secondary philosophical concept because it cannot simply appear in the mind when our senses make contact with the water. The concept cause is only acquaired when we analyze and compare the relationship between water and wet so that we find that the existence of wet depends on that of water. Wherever there is water, wet does exist. So, is causality real in the real world? Yes it is. Its existence, however, is different from that of sensual realities. Causation and other secondary philosophical concepts exist transcendentally, but not in the context of being essentially understood (whatness) ${ }^{50}$ Its existence is invisible to the physical senses, but obvious to one of the inner senses of the human soul, namely rationality. 


\section{f. Ittiḥ̂̄d al-Āqil wa al-Ma'qūl}

Ittihad al-'Aqqil wa al-Ma'qūl means 'the unification of the subject and the object of knowledge'. It is the theory of the production of knowledge. For Mulla Sadra, intellection or the proccess of producting knowledge is an existential unification between the subject and the object of intellection. This process involves three elements, subjects, objects and knowledge itself. As it has been discussed previously, when our senses perceive a reality, appears in our mind (soul) the quiddity of the object, which then becomes part of the subject's soul. ${ }^{51}$ The soul perceives the quiddity of each object to be known and molds it into a part of his existence. ${ }^{52}$ This unification occures existentially and spiritually, so it does not lead to essential changes such as quantity, size, shape and color of the two united things. Changes occur existentially in the soul of the subject (human), namely the degree of her soul's perfection, ${ }^{53}$ from being not knowing becomes being knowing something.

The kind of wujūd united with the subject's soul is called as-surah al-'aqliyyah or the intellect form. The intellect form, according to Sadra, acts as the mediator between the subject and object of knowledge. The subject can find out the object through its intellect form, and vice versa the object can be recognized by the subject through the form. Its function of mediation is just like the light which is visible by itself and able to make the other visible.$^{54}$ Ontologically, the intellect form is a mode of the object's graded wujūd to be able to unite or be present in the subject's soul in every process of intellection

\section{g. Motion}

In general, motion is understood as a change or positional shift. ${ }^{55}$ Ibn Rushd defines it as "the process of moving from one point to the next point by eliminating the first point and forming the second point, and so on". ${ }^{56}$ For Mullā Șadrā, motion is an integral part of the natural/physical world. According to his system of philosophy, wujūd is singular and it then grades to create diverse modes of existents. The lowest level of gradation constitutes what so-called the physical world, where the modes of graded wujüd reach the peak of its diversity. This is where space, time and motion come into being.

Each bodily entity is composed of substance and accidents. Substance is the part with the independent existence, while accidents are those dependent on the existence of substance. For Șadrā, motion occurs in the substance of every entity and as an effect the substance's movement causes in its accidents' movement. ${ }^{57}$ In another language, he calls substance as tabí' $a h$ 'nature'. ${ }^{58}$ If it stands still, so do the attributes leaning to it. But this is impossible, because everything in this material world is in a constant change. Tabi'ah exists in every reality, and constitutes the core of it. In each level, with this pattern all realities in the universe are moving, and motion is the nature of the wujūd in the level of gradation. Material realities are the farthest beam with the weakest intensity. Motion is the actualization of the return of the modes of wujūd toward its source of radiance. In other words, as the nature of realities it is the process of refinement of their wujūd, from potentiality towards actuality.

\section{h. an-Nafs (the Soul)}

Soul is the name for the substance of human, and its accident is called body. At the beginning of its creation, as in other realities, the human soul is the surah 'form' which gives actuality to $m \bar{a} d d a h / h a y \bar{u} l \bar{a}$ 'matter'. The unity of form and matter creates jism 'body'. Being different from matter which totally melts into the body, form (the soul) retains its independence. During its development, the soul is gaining its substantial role over the body. With this role, it becomes the perpetrator of the body's gestures. Without such substantial role of the soul, the body becomes merely a set of nerves that do not work. The life of the body comes from the soul. At the peak of its perfection in this earthly life, in its way of the transubstantial motion, the soul separates from the body. It reaches the level of the absolutely spiritual wujūd which is perpetual and closer to the 
Absolute, while the body decomposes and its elements become separated and united with various other physical substances.

Such substantial role is given because the soul in its essence is made up of several faculties with special functions each works. The faculties, over time, evolve "inside" the human body to the stages of perfection. There are three faculties, namely vegetable, animal and human. ${ }^{59}$ Such division is based on the hierarchy of perfection of wujūd among them. The higher, in addition to having a distinctive capability to itself, also has all the capabilities of the lower. The lowest is the vegetable soul (an-nafs na-nabätiyyah) which is the power that drives the digestive system, growth and breeding. The very level is equivalent to the soul of plants. The upper is the animal soul (an-nafs al-hayawāniyyah) which is the power that drives the rest of the body to function properly. It is also the source of human lust and anger. In addition, it is also the source of instinctual perception, namely the sensory perception of the objects around and a kind of consciousness in the simplest level. This level of human soul is equivalent to that of animals by which they are able to survive and create a bunch. The highest faculty is the human soul (an-nafs al-human), the power to carry out intellectual and spiritual perceptions so that she is able to acquire knowledge and the truth. ${ }^{60}$

The three faculties of the soul move or develop gradually. A human at the beginning of her development is in the form of a zygote, embryo and then fetus. In this phase, a new life grows on the plant level (an-nabātiyyah), so that the only physical activity she can do is growing up. After becoming a figure of the baby, her soul's quality of perfection rises to the level of animal (al-hayawāniyyah) and has started to move parts of the body and perform sensing. The soul then evolves into the nafsāni level in which the al-'aql 'rational power' as the unique ability of her soul starts to function. ${ }^{61}$ This power gives her the ability of thinking about herself and other things around, in order to obtain what is called sciences and haqiqqah. The chronological development of the faculties takes place following the law of transubstansial motion. The appearance of the latter does not mean denying the previous, but covering and refining. Each of the three faculties exists, but the overall forms of the three merge in the existential unity called "soul".

\section{The Existence of the State from the Perspective of Mullā Șadrā's Philosophy}

From the above discussion there are three theories that meet each other, and the three in each shape are non-empiricist, i.e collective consciesness by Alexander Wendt, 'asabiyyah by Ibn Khaldun, and social spirit by Mutahhari. All the three agree at least on two things: first, the state exists in the real world, not merely a fictitious concept; second, the existence of the state is unobservable-undetectable. We agree with the the three especially with Mutahhari's social spirit which expressly states the existence of society.

\section{a. The State Occupies A Certain Level of Wujūd}

Based on the principles of the principality of wujūd and gradation of wujūd, as the basis of all diverse realities wujūd in itself must be "something" singular and simple. Then, the Absolute Wujūd grades and bears modes of wujūd. At the furthest radiance, the physical world comes into being. Beyond it, stand numbers of the upper worlds which are more perfect because they are closer to the source. There the unobservable-undetectable spiritual realities dwell such as the soul, jinn, angels, heaven and hell.

The human soul is composed of some levels one of which is the mental dimension (adhdhihn) in which reside all the mental forms (al-suwar adh-dhihniyyah). On the one hand, the state is a mental reality which is born of the discourse about a political community. On the other, it is not purely mental, because most of its elements refer to sensual physical facts. President, ministers, members of parliament, the army, the people, territorial, are real. All are among the external manifestation of the state. In each format, the discourse about the state's figure exists in the mind of each person/citizen. This means that the existence of the state, Indonesia, for example, 
is collectively recognized by all individuals. It is not possible if it were an imagination while being recognized by hundreds of millions of people.

Mullā Șadrā says that the existence of spiritual beings is more lasting than physicalmaterial ones due to their higher level of wujūd. The state, its selfhood, is spiritual/nonmaterial although it has numbers of physical elements, then it is more enduring than its individual citizens. For example, Indonesia still exists despite its founders like Soekarno and Hatta are dead, the actors of governance change, and citizens come and go. If the state were only an illusion in the mind of a citizen, it would also be lost along with the damage or death of the person's mind. In fact, it is not the case.

\section{b. The State Exists Transcendentally}

Of the three types of concepts, the state does not fall into the category of primary concepts ( $m a^{\prime} q u \bar{l}$ àt awwaliyyah). While primay concepts like the concept of "glass" can be automatically abstracted when we see a glass, for the state it is required a lengthy analysis for us to arrive at a conception that we are part of the state called Indonesia, for example, even though we were born and have lived many years in Jakarta.

The state also does not fall into the category of logical secondary concepts having no contact to any extra-mental facts, because the concept of the state has footholds in the external world, such as territorial, people, officials, government offices, army and military forces, and others, which will never be conceived as such without the presence of the state. The objective events such as war, cooperation and coalition do not just happen, but there must be large systems that create and drive them. All such events and the underlying systems are integral parts of the "body", functions and activities pinned to a "figure" called the state.

All these characteristics indicate the state as a philosophical secondary concept. The five basic elements of the state above are also the philosophical secondary concepts each of which has its analysis and explanation. The conception of the state is gained through a complex analysis on the relations between these concepts. Like any other secondary philosophical concepts such as causality, something, actuality and potentiality, which are prevalent in the discourse of Islamic philosophy, the state is not just an abstraction or mental understanding. It also exists as an objective reality in the real world. However, its existence is different from the physical objects that become the mișda $q$ of primary concepts whose form and movement can sensually be detected. The state exists transcendentally. It exists not as a part but the whole of the constituent elements that are present simultaneously in the consciousness of a social group (society).

\section{c. The State's Existence is United in the Individual Consciousness}

According to the principle of Ittihad al-'âqil wa al-ma'qūl, every picture that appears in the mind when/after we perceive an external reality, it is no other but the reality itself which is present in our mind. Such picture is the intellect form of the actual figure in the extra-mental world specially created for the mind. When it comes to the mind that the figure of the state is beyond the physical elements that we see in reality, that is exactly the state. It is because any intellect form which is present in the mind when we are witnessing a sensuous object is just another dimension of the object itself. In this case of the state, not only does the mind capture quiddities or intellectual forms of the sensual objects like the president, ministers, councilors, army, police, bureaucratic officials, and so forth, but also existential relations which are unobservable-undetectable "behind "the physical appearance of these objects, and which connect, bind and move their bodies and consciousness.

Then, according to Sadra's epistemology, knowledge is the mode of wujūd in a particular level. ${ }^{62}$ Any knowledge about something is the thing itself which is present in the intellectual dimension. ${ }^{63}$ This unity does not occur in the material dimension but in the intellectual-spiritual, which is actively carried out in and by the soul of the subject. ${ }^{64}$ The state is the one whose true 
reality is invisible, but the soul as the true subject of intellection can see it. It is because the state is a spiritual figure which exists in the souls of its individuals. It means the state and the soul exist at the same dimension, i.e spiritual. At that moment of intellection the existence of the state is united with that of the subject's soul. It is present in its citizens' souls.

\section{E. The Conception of the State from the Perspective of Mullā Șadrā's Philosophy}

\section{a. The State is a "Half-Human Entity"}

What we have argued above is the state in the context as a form of society. In this context, it is a social person, namely the aggregate of shared goals, expectations, attitudes and actions of a number of people who live together in a territorial, while politically historically it is a concept or a new model of political organization born in the mid-17th century in the Europe. In this context, it is the actualization of the philosophical adage "man is a social creature", at the level of the five essential qualities: territorial, public policy, political institutions, the multiplicity of functions and activities of government, and the structures of legitimate authority.

Further discussion on the essence of the state will intersect with the realm of social science. Mulla Sadra himself, as already said above, does not speak in it. So we need to refer back to Mutahharī's ideas of society and develope it in the broader context. Mutahhari says that society is a group of people who live and are linked together by a set of systems, customs, rites and laws. ${ }^{65}$ This living group is a natural phenomenon. It is the basic human nature. ${ }^{66}$ Therefore, the creation of societies takes place naturally wherever there are a group of people living together. It means that a person's physical and mental activities are always related and involve others around. At some point of certain intimacy, a sense of unity and vision arises among them which is then transformed to form a social soul and turns to be a society.

From the perspective of Sadrā's philosophy, the human nature as a social entity can be understood as the effect of the existential oneness between them. All human beings, regardless of their differences to each other, are in the same level of wujūd both physically and psychologically. Such differences are the individuation (tashakhus) due to degrees of intensity of the graded Absolute Wujūd. They are, however, existentially clustered into a single species, namely humans, because their qualities of wujūd in general are in the equal level compared to any other realities in the world. As Sadrā said, a unification process is only possible between equal realities. ${ }^{67}$

The unity of wujūd then actualizes to be some sort of strong cohesion among the entities of the same species then translated as the nature of grouping among realities of the same level of wujūd. In human reality, such is what Mutahhari calls the nature of society. This cohesion causes animals and humans tend to congregate although the animal faculty of their souls allows them to move and change places. Being better than the animal, the human soul is equipped with the intellectual power (al-quwwah an-nätiqah) with whom they follow their trendency to group not only based on the needs of their animal faculty, but also on the unique needs and desires of human beings such as clothing, self-actualization, knowledge, worship, justice, position, fame and so forth. All these needs then actualize in the way of grouping that is far more advanced than that of animals. They build vision and mission, system of leadership/governance, law, culture, rituals, ethics, language, ideology, territory, military weapons, homes, and so forth. With all these atributes a group of people evolve into a more advanced type of grouping named "society". Some societies then develop their ways of organization to form what is called the state.

\section{b. The State as the Actualizaton of the Souls's Transubstantial Motion}

So far it has been found that the existential unity bears cohesion between the occupants of the same level of wujūd which manifests as the tendency of grouping between realities of the same species. In the moving realities like animals and humans, the tendency draw them to always get together with each other though they can move in all directions. With the power of perception, animals actualize it with the consciessness that grouping is the best way to satisfy all their needs. 
In humans, with the power of intellection the consciousness is far more advanced. They are aware that living in groups is not enough. Further efforts are needed to manage and regulate the attitude and actions of each member in achieving their needs and wants. So they make a deal to make one of them as leaders with certain rules agreed. From here the style of human groups is different from that of animals. As the number of individuals increase, so do the number and kinds of their needs while the availability in nature is very limited. In response, they change, develop I 88 and improve the quality of group settings until it comes to the limit currently known as the state. What makes the state different from other models of social organization is its system of leadership and involvement of all the individuals in it. The state allows all elements of its citizens involved in the regulation of their life together through a set of rights and obligations agreed upon. It also has the clear territorial to control and for its members to live. With such advantages, all individuals of the state feel as one soul, one body and one family.

Such social-psycological process is the actualization of the perpetual motion experienced by the substance of each individual of the group, i.e the soul. As described previously, motion is the nature of all realities in this physical world, and it happens on the substance that affects the motion of its accidents. Its direction is toward the perfection of wujūd. In human beings, the soul is the substance and the body is its accident. All human needs both physical and spiritual are the needs of their soul, because the body is only the locus for the soul's presence and activities in this worldy life and in the contect of his trip toward the perfection of wujūd. This means that gathering, group, society and the state as ways to complete all types and levels of their needs, are clearly done by the human souls as the actualization of their transubstantial motion. The same purpose (the perfection of wujūd), the same place of actuality (earth/territorial), and the same needs during the transubstansial trip, make the souls realize that togetherness and orderliness, especially with those closest physically, are the best choice. They form communities or social groups, such as family, tribe, village, town, province and country or state, with organisational systems that continue to grow and prosper

\section{F. Epilogue}

This research comes from a simple question, whether the state is real or metaphor. According to Alexander Wendt's mapping, the answer has been splitting contemporary IR scientists into two camps, the realist and anti-realist. ${ }^{68}$ Realists reply that the state exists or is real in the real world and its existence is not reduced to individuals in it. Anti-realists answer that it is only an imaginary concept in the mind. From the study on Mulla Sadra's philosophy here we conclude that the state exists independently, although its existence rests on the existence of the individual members. This fits with the anti-realists.

We found that the state is an aggregate figure of two dimensions, namely physical and spiritual/immaterial. In the physical dimension it is a set of human bodies along with their devices of life such as homes, offices, regions, self-defense tools, and so forth. In the spiritual dimension it is the personality of united souls among individuals living together in a territorial with an agreed governmental system, structures of power and normative instruments. This finding is in line with what Wendt found with his scientific realism that the state is a collective consciousness among individuals.

As a type of societies, the state is as an intelligent response of human beings over the potency of anarchy under the increasing number of individual members, on the one hand, and the limited natural resources on the other. As Mullā Șadrā said, "a man is dominated by selfishness and greed, so he always wants to beat each other." ${ }^{69} \mathrm{He}$ also said, "The system of government is born from the womb of the human souls as the best effort that can be done to arrange their shared living". ${ }^{70}$ This view is similar to Thomas Hobbes's that man is composed of two elements, desire and ratio. The former encourages individuals to outperform, master and destroy each other. This creates a condition of anarchy in their togetherness which can only be mitigated by the presence of the giant (the great Leviathan) called the state. The giant intervenes and regulates the chaos that 
occurs among them. ${ }^{71}$ In IR, such Hobbesian theory of anarchy underlies the theory of anachy of international system formulated by neorelists.

In Mullā Șadrā's psycology, human needs are two kinds, bodily and spiritual. Both types, in the context of the state, actualize into national interests of the state. Therefore, there are also two kinds of national interests, material such as economy, trade and security, and non-material such as justice, technology and science. This finding is very close to constructivism, an IR school that makes immaterial factors such as identity, norms, discourses and religious beliefs, as important variables in the analysis of states' behavior and their relationship with each other, as the material such as economic, military and political interests.

In conclusion, Mulla Sadra's philosophy and a bit of his political theory when interpreted and adopted in IR context will result in new and unique findings, which turn out to be a lot of similarities and differences with the existing schools.

\section{NOTES}

${ }^{1}$ Thomas S. Kuhn, the Structure of Scientific Revolutions (Second Edition, Enlarged) (Chicago: the University of Chicago Press, 1970), 10-11.

${ }^{2}$ H.F. Holsti, "States and Statehood", in Richard Little and Michael Smith (ed), Perspectives on World Politics (Third Edition) (New York: Routledge, 2006), 19.

3 Holsti, States and Statehood, 18-19.

4 Erik Ringmar, "On the Ontological Status of the State," European Journal of International Relations (New York: Sage Publications, Vol. 2:4, 1996): 439-466.

5 Based on the Hobbesian doctrine, neorealists believe that anarchy is the basic character of the international system. International relationship is built upon the mutual motivation to defend, compete and dominate each other. At the international level, between states, there is no Leviathan to control and organize the anarchy. Robert M. A Crawford, Idealism and Realism in International Relations: Beyond the Disciplilne (New York: Routledge, 2000), 32 \& 36.

6 Robert Gilpin, "The Richness of the Tradition of Political Realism," International Organization (Massachusetts: the Massachusetts Institute of Technology and the World Peace Foundation, Vol. 38 No. 2, Spring, 1984): 301.

7 Herbert Spencer, The Man Versus The State (Idaho: the Caxton Printers, Ltd, 1960), 141.

8 Spencer, The Man Versus The State, 65.

9 Anjan Chakravartty, A Metaphysic for Scientific Realism: Knowing the Unobservable (New York: Cambridge University Press, 2007), 8.

10 Alexander Wendt, Social Theory of International Politics (Cambridge: Cambridge University Press, 1999), 216.

${ }^{11}$ Wendt, "The State as Person in International Theory," Review of International Studies (London: British International Studies Association, Vol. 30, 2004), 309-310.

12 Wendt, The State as Person in International Theory, 311-313.

13 Wendt, The State as Person in International Theory, 311-313.

14 Wendt, The State as Person in International Theory, 314.

${ }^{15}$ Robert Audi, The Cambridge Dictionary of Philosophy (Cambridge: Canbridge University Press, 1999), 684.

${ }^{16}$ Audi, The Cambridge Dictionary of Philosophy, 686.

${ }^{17}$ Wendt, Social Theory of International Politics, 49.

18 The concept of the state as a new model of social organization is born in the 17th century in Europe. Only in the 20th century, through the long history of European colonialism, it was agreed globally as the model of an ideal social organization. See Holsti, States and Statehood, 23; Mathias Albert, et al., Identities Borders Orders: Rethinking International Relations Theory (Minneapolis: The University of Minnesota Press, 2001), 34.

19 'Abd al-Raḥmān Ibn Khaldūn, The Muqaddimah: an introduction to history, trans. Franz Rosethal (Princeton: Princeton University Press, 1969), 475.

20 'Abd al-Raḥmān Ibn Khaldūn, Muqaddimah Ibn Khaldūn (Beirut: Dār al-Fikr, 2001), 160-161.

21 Ibn Khaldūn, Muqaddimah Ibn Khaldūn, 121-122.

${ }^{22}$ Ibn Khaldūn, Muqaddimah Ibn Khaldūn, 121-122.

${ }^{23}$ Ibn Khaldūn, Muqaddimah Ibn Khaldūn, 109-110. 
${ }^{24}$ Ibn Khaldūn, Muqaddimah Ibn Khaldūn, 121.

${ }^{25}$ Murtadha Muṭahharī, Masyarakat dan Sejarah: Kritik Islam atas Marxisme dan Teori Lainnya (Bandung: Penerbit Mizan, 1993), 15.

${ }^{26}$ Muțahharī, Masyarakat dan Sejarah, 15-18.

27 Muțahharī, Masyarakat dan Sejarah, 21.

${ }^{28}$ Muțahharī, Masyarakat dan Sejarah, 21.

${ }^{29}$ Muțahharī, Masyarakat dan Sejarah, 22.

${ }^{30}$ S.M. Khamenei, Mullā Sadrra's Trancendent Philosophy (Teheran: SIPRIn, 2004), 50.

${ }^{31}$ Ibrahim Kalin, "Mullā Șadrā's Realist Ontology of the Intelligibles and Theory of Knowledge," The Muslim World (Istambul: ISAM, Vol. 94, Issue 1, Januari, 2014): 9.

32 'Abd al-Jabbār ar-Rifâ' '̄, Durūs fì al-Falsafah al-Islāmiyyah: Sharh Taudīhī li Kitāb Bidāyah al-Himah (Iran: Al-Hadi, 2000), 152-153.

33 Mullā Sadrā, al-Hikmah al-Muta'āliyyah fì Al-Asfār al- 'Aqliyyah al-Arba'ah (Beirut: Dar al-Iḥyā alTurats al-'Arabi, 1981), V. 1, 39.

${ }^{34}$ Fazlur Rahman, The Philosophy of Mullā Sadrā (Albany: SUNY Press, 1975), 28.

${ }^{35}$ Șadrā, Al-Hikmah al-Muta'àliyyah, V. 2, 289; Khamenei, Mullā Sadrā's Transcendent Philosophy, 52.

36 Rahman, The Philosophy of Mullā Sadrā, 28.

${ }^{37}$ Șadrā, al-Hikmah al-Muta'āliyyah, V. 1, 87.

${ }^{38}$ Seyyed Hossein Nasr, Three Muslim Sages (New York: Caravan Books, 1997), 25-26.

39 Rahman, The Philosophy of Mullā Sadrā, 34-35

${ }^{40}$ Șadrā. Al-Hikmah al-Mutāliyyah, V. 1, 434.

${ }^{41}$ Șadrā, Al-Hikmah al-Mutāliyyah, V. 1, 433-434.

${ }^{42}$ Șadrā, Al-Hikmah al-Mutāliyyah, V. 1, 433-434.

${ }^{43}$ Khamenei, Mullā Sadrra's Trancendent Philosophy, 82.

${ }^{44}$ Khamenei, Mullā Sadrra's Trancendent Philosophy, 82.

45 Muțahharī, Durūs Durūs Falsafiyyah fì Sharh al-Mandhūmah (Lebanon: Shams al-Mashreq for The Cultural Services, 1994), V. 2, 3.

${ }^{46}$ Muțahharī, Durūs Falsafiyyyah, V. 2, 3.

${ }^{47}$ Mohsen Gharawiyan, Pengantar Memahami Buku Daras Filsafat Islam (Jakarta: Sadra Press, 2012), 62.

${ }^{48}$ Gharawiyan, Pengantar Memahami Buku Daras Filsafat Islam, 62.

49 Muțahharī, Durūs Falsafiyyyah, V. 28.

${ }^{50}$ Muțahharī, Durūs Falsafiyyyah, V. 2, 27.

${ }^{51}$ Șadrā, al-Hikmah al-Muta'àliyyah, V.3, 337.

${ }^{52}$ Șadrā, al-Hikmah al-Muta'àliyyah, V.3, 339.

53 Șadrā, al-Hikmah al-Muta'àliyyah, V. 3, p 377-378.

${ }^{54}$ Șadrā, al-Hikmah al-Muta'àliyyah, V. 3, 318.

${ }_{55}$ Kamus Besar Bahasa Indonesia, (Jakarta: Pusat Bahasa Departemen Pendidikan Nasional, 2008), 475.

56 Khalid al-Walid, Perjalanan Jiwa Menuju Akhirat: Filsafat Eskatologi Mullā Șadrā (Jakarta: Șadrā Press, 2012), 49.

${ }^{57}$ Țabațaba'1̄i, Bidāyah al-Hikmah (Qom: Muassasah an-Nasyr al-Islami, No. Year ), 88.

${ }^{58}$ Muhammad Kamal, "Dressing after Dressing: Șadrā's Interpretation of Change," Open Journal of Philosophy (SciRes, http://dx.doi.org/10.4236/ojpp.2013.31009, Vol. 3, No. 1, 2013); 58; Șadrā, alHikmah al-Muta'áliyyah, V. 3, 62.

${ }^{59}$ Șadrā, al-Hikmah al-Muta 'āliyyah, V. 8, 129-130.

${ }^{60}$ Șadrā, al-Hikmah al-Muta'äliyyah, V. 8, 130.

${ }^{61}$ Șadrā, al-Hikmah al-Muta'áliyyah, V. 8, 136.

${ }^{62}$ Șadrā, al-Hikmah al-Muta'àliyyah, V. 3, 377-378

${ }^{63}$ Șadrā, al-Hikmah al-Muta'àliyyah, V. 3, 382.

${ }^{64}$ Șadrā, al-Hikmah al-Muta'àliyyah, V. 3, 382.

65 Muțahharī, Masyarakat dan Sejarah, 15.

${ }^{66}$ Muțahharī, Masyarakat dan Sejarah, 15-18.

${ }^{67}$ Șadrā, al-Hikmah al-Muta 'āliyyah, V. 3, 315-316.

${ }^{68}$ Wendt, Social Theory of International Politics, 47-50.

69 Șadrā, Ash-Shawāhid ar-Rubūbiyyah fĩ al-Manāhij as-Sulūkiyyah (Mashhad: Meshed University Press, 1967), 363.

${ }^{70}$ Șadrā, Ash-Shawāhid ar-Rubübiyyah, 365.

71 Thomas Hobbes, Leviathan (Harmondsworth: Penguin, 1651/1968), 185-186. 